\title{
PENERAPAN METODE DISCOVERY DENGAN MEDIA FLASHCARD UNTUK MENINGKATKAN HASIL BELAJAR IPA POKOK BAHASAN PEMBENTUKAN TANAH PADA SISWA AUTIS KELAS V SLB - B \& AUTIS TPA JEMBER
}

\author{
JARIYATUR ROBIAH, S.Pd
}

SLB-B DAN AUTIS TPA JEMBER

\begin{abstract}
Abstrak
Tujuan penelitian ini adalah untuk mendeskripsikan penerapan metode discovery dengan media flashcard untuk meningkatkan hasil belajar IPA pokok bahasan pembentukan tanah pada siswa kelas V SLB - B \& autis TPA Jember semester genap tahun pelajaran 2018/2019. Subyek penelitian ini adalah mata pelajaran IPA, khususnya pada pokok bahasan tentang pembentukan tanah, pada siswa kelas V SLB - B \& Autis TPA Jember, dengan jumlah siswa 3 anak. Pelaku tindakan kelas adalah guru kelas $\mathrm{V}$ yang dibantu oleh teman sejawat dan kepala sekolah selama melaksanakan penelitian. Tempat penelitian pembelajaran adalah di SLB - B \& Autis TPA Jember kabupaten Jember. Penelitian dilaksanakan dalam dua siklus, siklus I rentang tanggal $4-8$ februari 2019, siklus II pada rentang tanggal 11 - 15 februari 2019 dan sesuai dengan jadwal kegiatan. Penelitian ini di bantu oleh teman sejawat sebagai rekan kerja dan pengamat dalam penelitian ini. Hasil penelitian ini yaitu hasil belajar IPA pada pokok bahasan pembentukan tanah di kelas V SLB - B \& Autis TPA Jember dapat meningkat melalui penerapan metode discovery dengan media flashcard. Hal ini dapat dilihat bahwa pada siklus I, dari 3 siswa yang tuntas sebanyak 2 siswa (66\%) dan yang belum tuntas sebanyak 1 siswa lain (34\%). Sedangkan pada siklus II, semua siswa telah tuntas (100\%). Jadi, dari siklus I ke siklus II ada peningkatan hasil belajar sebesar 34\%.
\end{abstract}

Kata kunci: metode discovery, media flashcard, hasil belajar IPA, pembentukan tanah

\section{PENDAHULUAN}

Manusia dalam kehidupan seharihari tidak bisa lepas dari pendidikan. Pendidikan merupakan suatu hal yang perlu kita kaji atau pelajari, karena pendidikan sangat bermanfaat dan berpengaruh bagi kehidupan masyarakat. Pendidikan diwajibkan kepada siapa saja tidak hanya kepada anak yang normal saja tapi juga kepada mereka yang berkebutuhan khusus sesuai dengan UUD 1945 pasal 31 mengatakan bahwa "setiap warga negara berhak mendapat pendidikan" sehingga tercapainya tujuan pendidikan nasional yang terdapat pada pasal 3 Undang-Undang Nomor 20 Tahun 2003 tentang Sistem Pendidikan Nasional http://doi.org/10.31537/speed.v3i2.281 yaitu mengembangkan potensi peserta didik agar menjadi manusia yang beriman dan bertakwa kepada Tuhan Yang Maha Esa, berakhlak mulia, sehat, berilmu, cakap, kreatif, mandiri, dan menjadi warga negara yang demokratis dan bertanggung jawab. Jadi, pendidikan itu dilakukan secara merata sehingga memberikan kesempatan untuk memperoleh layanan pendidikan dan peningkatan mutu kepada setiap warga negara, tak terkecuali kepada anak berkebutuhan khusus.

$$
\text { Pendidikan juga disesuaikan }
$$
dengan minat dan kebutuhan anak. Berdasarkan Undang-undang Sisdiknas No. 20 Tahun 2003 Pasal 40 ayat 2 "Pendidikan dan tenaga kependidikan berkewajiban menciptakan suasana 
pendidikan yang bermakna, menyenangkan, kreatif, dinamis, dan dialogis, serta mempunyai komitmen secara profesional untuk meningkatkan mutu pendidikan."

Sesuai dengan pernyataan di atas maka pendidik diwajibkan sekreatif mungkin untuk menciptakan pembelajaran yang menyenangkan bagi setiap anak, baik itu anak normal maupun anak yang berkebutuhan khusus seperti anak autis. Dengan diciptakannya pembelajaran yang sesuai dengan minat dan potensi anak, hasil belajar anakpun meningkat. Pembelajaran yang dimodofikasi akan menjadikan anak memiliki pengetahuan yang luas sehingga tujuan pendidikanpun tercapai.

Aswandi (2019, hlm.

menformulasikan pengertian autisme Secara etimologi yaitu berasal dari kata "auto"dan "isme". Auto yang artinya dirinya sendiri sedangkan isme adalah suatu aliran/paham. Dengan demikian autism diartikan sebagai sesuatu paham yang hanya tertarik pada dunianya sendiri. Yuniar (Sujarwanto, 2005, hlm. 42) mengemukakan autis adalah gangguan perkembangan yang kompleks, mempengaruhi perilaku dengan akibat kurang mampu dalam komunikasi, hubungan sosial dan emosional dengan orang lain, sehingga sulit untuk mempunyai keterampilan dan pengetahuan yang diperlukan sebagai anggota masyarakat.

IPA berkaitan dengan cara mencari tahu dan memahami alam secara sistematik, sehingga IPA bukan hanya penguasaan kumpulan pengetahuan berupa fakta, konsep, dan prinsip saja tetapi juga merupakan suatu proses penemuan. Pendidikan IPA diharapkan dapat menjadi wahana bagi peserta didik untuk mempelajari diri sendiri dan alam sekitar, serta prospek pengembangan lebih lanjut dalam menerapkannya untuk melanjutkan pendidikan selanjutnya (Depdiknas, 2006, hlm. 480). Titik sentral pendidikan IPA adalah terletak pada kualitas proses pembelajaran yang terjadi di dalam kelas. Hal ini penting karena hanya dengan pembelajaran yang baik, siswa dapat meningkatkan pemahamannya terhadap konsep-konsep IPA.

Perkembangan dari bidang IPA tidak mungkin terjadi bila tidak disertai dengan peningkatan mutu pendidikan IPA, sedangkan selama ini pelajaran IPA dianggap sebagai pelajaran yang sulit. Hal ini dapat dilihat dari Nilai mata pelajaran IPA yang rata-rata masih rendah bila dibandingkan dengan pelajaran lainnya. Ini menunjukkan masih rendahnya mutu pelajaran IPA.

Oleh karena itu, diperlukan suatu upaya dalam rangka meningkatkan mutu pendidikan dan pengajaran salah satunya adalah dengan memilih strategi atau cara dalam menyampaikan materi pelajaran agar diperoleh peningkatan prestasi belajar siswa khususnya pelajaran IPA. Misalnya dengan membimbing siswa untuk bersamasama terlibat aktif dalam proses pembelajaran dan mampu membantu siswa berkembang sesuai dengan taraf intelektualnya akan lebih menguatkan pemahaman siswa terhadap konsepkonsep yang diajarkan. Pemahaman ini memerlukan minat. Tanpa adanya minat 
menandakan bahwa siswa tidak mempunyai motivasi untuk belajar. Untuk itu, guru harus memberikan stimulus dalam bentuk motivasi sehingga dengan bantuan itu anak didik dapat keluar dari kesulitan belajar.

Berdasarkan observasi awal di SLB - B \& Autis TPA Jember khususnya anak-anak yang ada di kelas dasar V. Anak-anak tersebut sudah bisa berinteraksi dan berkomunikasi dengan orang lain, meskipun ia masih sulit melakukan kontak mata dengan lawan bicaranya dan intonasi suaranya tidak teratur namun maknanya bisa dimengerti. Menurut keterangan dari orang tuanya, anak ini mempunyai daya ingat yang kuat. Terbukti ketika ia mampu menggambar dan menyebutkan macam-macam bendera beserta negaranya, begitu pula dengan gambargambar lain yang sering ia lihat meskipun, anak ini kadang bingung ketika mendapati serangkaian gambar yang sejenis tapi tidak sama dan tidak tahu maksud hubungan gambar satu dengan gambar lainnya. Jika diberi penjelasan, anak ini tidak suka dan acuh. Sering sekali ia tampak bosan dan tidak tertarik jika diberi pembelajaran dengan metode ceramah. Oleh karena itu, dalam kegiatan pembelajaran sehari-hari anak ini cuma diberi buku oleh gurunya. Tetapi ketika belajar anak ini cenderung menyukai halaman buku yang bergambar dan berwarna, dibanding dengan halaman buku yang hanya berisi bacaan saja.

Padahal dalam mata pelajaran IPA tidak semua materi disajikan dalam bentuk gambar sehingga anak sering melangkahi materi yang tidak bergambar atau yang menurutnya tidak menarik. Hal ini mengakibatkan banyak materi yang tidak ia pelajari. Sehingga membuat hasil belajar anak rendah. Berdasarkan permasalahan tersebut, penulis berkesimpulan bahwa anak ini tertertarik dengan pembelajaran yang berbentuk visual berupa gambar.

Berdasarkan latar belakang di atas, maka penulis beranggapan bahwa penerapan Metode Discovery dengan Media Flashcard, karena media ini sebagai penunjang pembelajaran di dalam kelas dapat dijadikan media pembelajaran untuk menarik perhatian anak autis agar lebih memperhatikan dan lebih fokus kepada pelajaran yang diberikan guru, sehingga hasil belajar IPA anak meningkat. Oleh karena itu, penulis tertarik untuk mengkaji masalah meningkatan hasil belajar anak autis dalam pelajaran IPA melalui penerapan media Flashcard. Pentingnya media Flashcard dalam proses pembelajaran memberikan peran aktif bagi anak, karena media ini berupa gambar yang berwarna dan menarik, dipindahpindah oleh anak serta dapat disetting untuk belajar individu maupun kelompok.

Dalam konteks pendidikan termasuk pendidikan anak autis, umumnya yang menjadi tolak ukur atau barometer keberhasilan pencapaian tujuan pembelajaran adalah hasil belajar. Maksudnya untuk mengetahui berhasil tidaknya pencapaian tujuan pembelajaran dilihat dari hasil belajar anak. Penulis berharap hasil belajar anak autis bisa lebih meningkat setelah dilakukannya pembelajaran menggunakan media Flashcard. Oleh 
karena itu, maka penulis tertarik untuk mengambil judul, "Penerapan Metode Discovery dengan Media Flashcard untuk Meningkatkan Hasil Belajar IPA Pokok Bahasan Pembentukan Tanah Pada Siswa Kelas V SLB - B \& Autis TPA Jember."

Tujuan penelitian ini adalah untuk mendeskripsikan Penerapan Metode Discovery dengan Media Flashcard untuk Meningkatkan Hasil Belajar IPA Pokok Bahasan Pembentukan Tanah Pada Siswa Kelas V SLB - B \& Autis TPA Jember.

\section{METODE}

Subyek penelitian ini adalah mata pelajaran IPA, khususnya pada pokok bahasan tentang Pembentukan Tanah, pada siswa kelas V SLB - B \& Autis TPA Jember Kabupaten Jember, dengan jumlah siswa 3 anak. Pelaku tindakan kelas adalah guru kelas $\mathrm{V}$ yang dibantu oleh teman sejawat dan kepala sekolah selama melaksanakan penelitian.

Tempat penelitian pembelajaran adalah di SLB - B \& Autis TPA Jember. Adapun waktu penelitian pembelajaran ini dilakukan pada semester Genap tahun pelajaran 2018/2019.

Penelitian dilaksanakan dalam dua siklus, siklus I rentang tanggal $4-8$ Februari 2019, siklus II pada rentang tanggal 11 - 15 Februari 2019 dan sesuai dengan jadwal kegiatan. Penelitian ini di bantu oleh teman sejawat sebagai rekan kerja dan pengamat dalam penelitian ini.

Penelitian ini menggunakan desain penelitian tindakan kelas (PTK). Pada hakekatnya PTK merupakan suatu proses dimana melalui proses ini guru menginkan adanya perbaikan, peningkatan, dan perubahan pembelajaran lebih baik agar tujuan pembelajaran dapat tercapai secara optimal.

http://doi.org/10.31537/speed.v3i2.281
Penelitian ini dilaksanakan berupa proses berdaur yang terdiri dari empat tahap. Keempat tahap tersebut dipandang sebagai siklus spiral dan dapat digambarkan sebagai berikut:

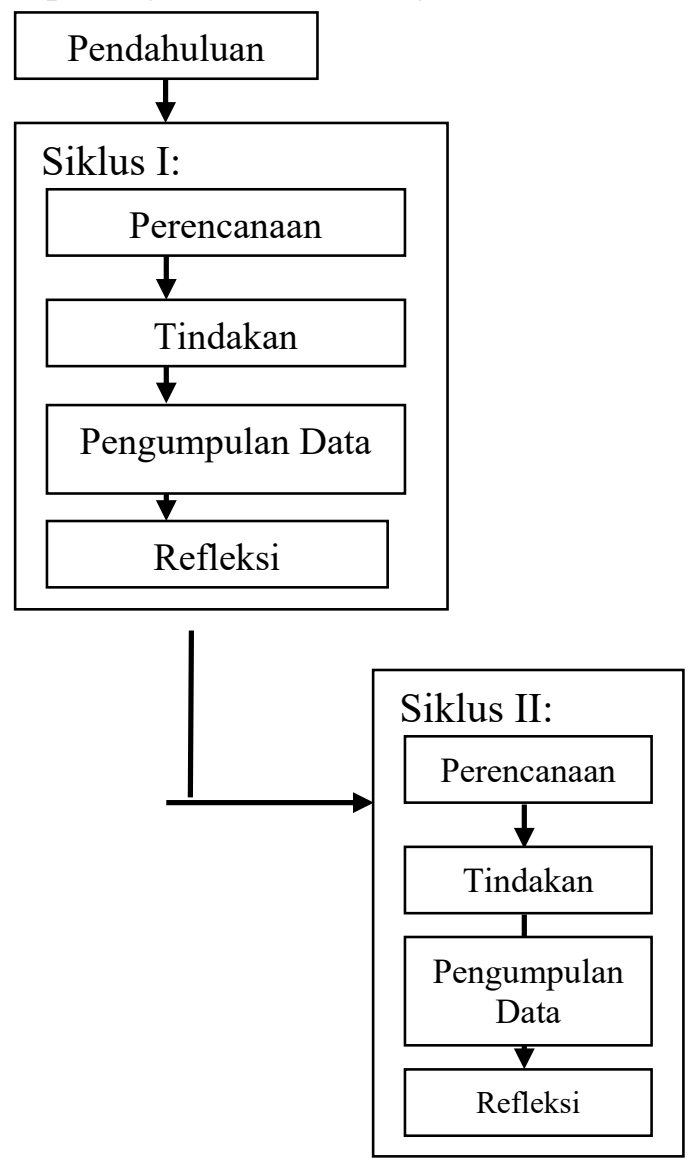

\section{Gambar 1. Alur Penelitian Tindakan Kelas}

Sebelum melakukan penelitian pada tahap ini peneliti menyusun rumusan masalah, tujuan penelitan, serta membuat rencana tindakan yang akan dilaksanakan pada proses pembelajaran. Selain itu, tahap ini juga dipersiapkan instrumen penelitian dan Rencana Pelaksanaan Pembelajaran yang akan digunakan.

Pada tahap ini tindakan yang harus dilaksanakan peneliti sebagai upaya untuk melaksanakan perbaikan kegiatan belajar mengajar serta mengamati hasil dan proses kegiatan 
belaar mengajar yang dilakukan oleh teman sejawat.

Pada tahap penggumpulan data peneliti berusaha mengumpulkan data untuk mendapatkan hasil.

Pada tahap refleksi, peneliti bersama guru dan teman sejawat sebagai pengamat melihat serta mempertimbangkan hasil dan dampak dari tindakan yang telah dilakukan.

\section{Siklus I}

Tahap pertama yaitu perencanaan perbaikan yang terdiri dari Penyusunan RPP (Rencana Pelaksanaan Pembelajaran) untuk observasi proses pembelajaran yang bisa dilakukan guru, pada pelajaran IPA. Banyak ditemukan kesalahan konsep ketika guru menerangkan materi pelajaran. Setelah itu, peneliti menyusun rencana pembelajaran dengan Metode Discovery menggunakan Media Flashcard berdasarkan materi pelajaran yang diberikan.

Kegiatan selanjutnya terdiri dari kegiatan merumuskan tujuan pembelajaran, menyusun langkahlangkah pembelajaran, merencanakan alat yang sesuai dengan pokok bahasan yang akan diajarkan. Mempersiapkan daftar pengamatan sebagai acuan untuk mengumpulkan data tentang hasil belajar siswa dalam mengikuti pelajaran IPA serta menyiapkan bahan penelitian. Memberikan tes di akhir pelajaran yang dimaksudkan untuk mengetahui perkembangan hasil belajar siswa.

Tahap kedua yaitu pelaksanaan perbaikan. Saat pelaksanaan tindakan, peneliti bertindak sebagai guru dibantu oleh teman sejawat sebagai pengamat yang memantau jalannya proses pembelajaran yang hasilnya berupa rekaman data kegiatan.

Guru melaksanakan pembelajaran dengan Metode Discovery menggunakan Media Flashcard, dengan langkah-langkah berikut: Guru membagikan kartu Flashcard bergambar kepada masing-masing siswa yang bertuliskan jenis-jenis pelapukan batuan dan susunan tanah, Guru menulis kategori jenis-jenis pelapukan batuan dan susunan tanah di papan tulis, siswa diminta untuk menemukan kategori kartu yang sama, siswa diminta untuk menempelkan kartu di papan tulis sesuai dengan kategori yang telah ditentukan, Guru membahas dan menyampaikan point-point penting.

Tahap selanjutnya yaitu pengumpulan data. Pada waktu guru mengajar, peneliti dibantu teman sejawat untuk melakukan pengumpulan data dengan cara observasi/pengamatan, wawancara, dan dokumentasi, selama kegiatan pembelajaran berlangsung untuk mengetahui sejauh mana data hasil belajar siswa sebelum dan sesudah diberi tindakan. Untuk mengetahui perkembangan hasil belajar, siswa diberi angket hasil belajar pada awal kegiatan sebelum melakukan tindakan dan juga pada lembar jawaban observasi hasil belajar yang dibawa peneliti. Untuk mengetahui perkembangan hasil belajar siswa dilakukan melalui tes yang diberikan setiap akhir siklus.

Pada tahap refleksi, dari hasil observasi, dilakukan analisis pada tindakan I kemudian dilanjutkan dengan refleksi yang dilakukan bersama teman sejawat, perlu dilakukan tindakan selanjutnya. Pada siklus II sama dengan 
pelaksanaan siklus I, hanya pada pelaksanaan siklus II berdasarkan pada hasil refleksi siklus I.

Instrumen pengumpulan data yang digunakan dalam penelitian ini adalah:

1. Lembar

Observasi

(Pengamatan)

Lembar observasi

adalah lembar yang berfungsi untuk mengamati dan mengukur tingkat keberhasian atau ketercapaian tujuan pembelajaran pada kegiatan pembelajaran di kelas. Lembar ini digunakan untuk mengamati peneliti dalam kegiatan perbaikan pembelajaran dengan Metode Discovery menggunakan Media Flashcard.

2. Tes Formatif

Tes formatif adalah tes-tes yang dilakukan selama proses pembelajaran yang masih berlangsung, agar siswa dan guru memperoleh informasi (feedback) mengenai kemajuan yang telah dicapai.

Dalam penelitian tindakan kelas, analisis data yang digunakan juga bersifat reflektif, artinya selalu direfleksikan pada proses pembelajaran. Dengan demikian setiap akhir pelaksanaan tindakan dilakukan kajian terhadap kelemahan kemudian diwujudkan dalam perbaikan rencana tindakan, setelah itu dilaksanakan ke dalam pelaksanaan tindakan siklus berikutnya.
Analisis data pada penelitian ini menggunakan statistik deskriptif. Menata, menyajikan, dan menganalisis data dapat dilakukan dengan menentukan skor rata-rata hitung dan persen/proposisi. Data disajikan dalam bentuk persentase untuk mengetahui peningkatan hasil belajar siswa. Hasil analisis tersebut menggambarkan hasil belajar IPA pokok materi Pembentukan Tanah melalui metode Discovery menggunakan Media Flashcard.

Untuk menghitung persentase peningkatan hasil belajar siswa digunakan dengan teknik sebagai berikut:

$$
P t=\frac{n}{N} \times 100 \%
$$

Keterangan:

$\mathrm{Pt}$ : persentase peningkatan hasil belajar siswa

$\mathrm{n}$ : jumlah siswa yang mengalami ketuntasan belajar

$\mathrm{N}$ : jumlah seluruh siswa

Untuk menentukan peningkatan hasil belajar diperoleh dari perubahan skor hasil belajar pra siklus ke siklus I, siklus II, atau siklus berikutnya.

Tabel 1. Kategori Persentase Hasil Belajar Siswa

\begin{tabular}{|c|c|}
\hline Skor rata-rata & Kategori \\
\hline $\mathrm{P} \geq 90 \%$ & Sangat Baik \\
\hline $80 \% \leq \mathrm{P}<90 \%$ & Baik \\
\hline $65 \% \leq \mathrm{P}<80 \%$ & Cukup Baik \\
\hline $55 \% \leq \mathrm{P}<65 \%$ & Kurang Baik \\
\hline $\mathrm{P}<55 \%$ & Sangat Kurang \\
\hline
\end{tabular}

Sumber: Nurkanca (1990:93)

HASIL DAN PEMBAHASAN

Siklus I 
Tindakan siklus I dilaksanakan pada hari Senin tanggal 04 Februari 2019. Waktu yang dibutuhkan yaitu dua jam pelajaran atau 2 x 35 menit. Pelaksanaan pembelajaran pada Siklus I ini sesuai dengan Rencana Pelaksanaan Pembelajaran (RPP) I, yang disusun dengan langkah-langkah pembelajaran yang meliputi: kegiatan awal, kegiatan inti, dan kegiatan akhir.

Tindakan siklus I ini dilaksanakan dengan menerapkan proses pembelajaran menggunakan Metode Discovery dengan Media Flashcard pada pokok bahasan tentang Pembentukan Tanah, dengan langkahlangkah sebagaimana tertuang dalam Rencana Pelaksanaan Pembelajaran (RPP) I.

Observasi dilaksanakan bersama proses pembelajaran melalui lembar pengamatan yang meliputi, aktifitas siswa, pengembangan materi, motivasi siswa dalam kegaitan pembelajaran, proses pembelajaran, serta hasil pembelajaran melalui tes akhir.

Data hasil belajar pada kegiatan siklus 1 yang diambil kepada siswa di akhir kegiatan Siklus 1. Secara terperinci hasil belajar IPA pada pokok bahasan Pembentukan Tanah dapat dijelaskan pada tabel berikut.

Tabel 2. Hasil Belajar IPA kelas V Siklus I

\begin{tabular}{|c|l|c|l|}
\hline No & \multicolumn{1}{|c|}{$\begin{array}{c}\text { Nama } \\
\text { siswa }\end{array}$} & $\begin{array}{c}\text { Nilai } \\
\text { Siklus } \\
\text { I }\end{array}$ & Ketuntasan \\
\hline 1 & Fauzan & 60 & $\begin{array}{l}\text { Belum } \\
\text { Tuntas }\end{array}$ \\
\hline 2 & $\begin{array}{l}\text { Dani } \\
\text { Firmansyah }\end{array}$ & 75 & Tuntas \\
\hline 3 & Riva Akbar & 70 & Tuntas \\
\hline
\end{tabular}

http://doi.org/10.31537/speed.v3i2.281

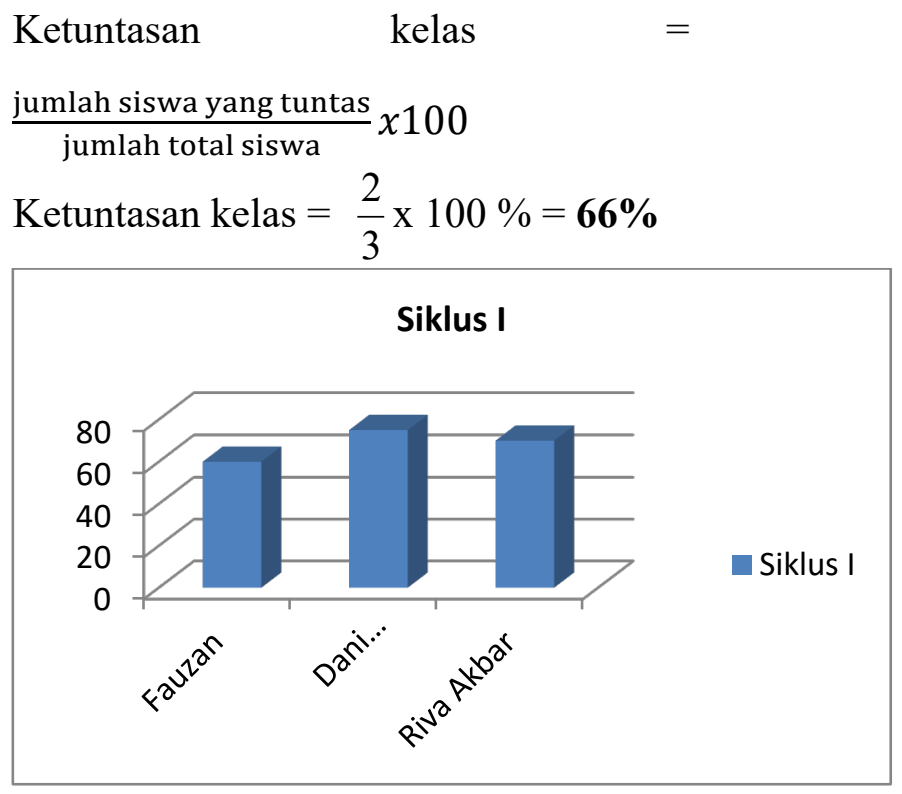

\section{Gambar 2. Grafik Hasil Belajar IPA Kelas V Siklus I}

Berdasarkan tabel di atas, pada siklus I masih belum menunjukkan hasil yang memuaskan bahwa kemampuan siswa dalam memahami materi pembelajaran tentang Pembentukan Tanah menggunakan Metode Discovery dengan Media Flashcard, hasil belajar siswa serta pemahaman terhadap materi pembelajaran masih kurang maksimal. Hasil tersebut menunjukkan bahwa pada siklus pertama secara klasikal siswa belum tuntas belajar, karena siswa yang memperoleh nilai di atas KKM yaitu $\geq$ 70 hanya sebesar $66 \%$ lebih kecil dari prosentase ketuntasan yang dikehendaki yaitu sebesar $85 \%$.

\section{Siklus II}

Tindakan siklus II dilaksanakan pada hari Senin tanggal 11 Februari 2019. Waktu yang dibutuhkan yaitu dua jam pelajaran atau 2 x 35 menit. Pelaksanaan pembelajaran pada Siklus II ini sesuai dengan Rencana Pelaksanaan Pembelajaran (RPP) II, yang disusun dengan langkah-langkah 
pembelajaran yang meliputi: kegiatan awal, kegiatan inti, dan kegiatan akhir.

Tindakan siklus II ini dilaksanakan dengan menerapkan proses pembelajaran menggunakan Metode Discovery dengan Media Flashcard pada pokok bahasan tentang Pembentukan Tanah, dengan langkahlangkah sebagaimana tertuang dalam RPP II. Perbedaan dengan siklus I tertelak pada variasi dalam penerapan Metode Discovery dengan Media Flashcard. Pada siklus I, kartu yang dibagikan hanya berupa tulisan contoh Pembentukan Tanah saja. Namun pada siklus II, kartu Flashcard yang dibagikan berupa gambar-gambar menarik disertai dengan tulisan.

Observasi dilaksanakan bersama proses pembelajaran melalui lembar pengamatan yang meliputi, aktifitas siswa, pengembangan materi, motivasi siswa dalam kegaitan pembelajaran, proses pembelajaran, serta hasil pembelajaran melalui tes akhir. Pada siklus II ini peneliti berusaha untuk memperbaiki kekurangan dan kelemahan pada siklus I.

Data hasil belajar pada kegiatan siklus II yang diambil kepada siswa di akhir kegiatan Siklus II. Secara terperinci hasil belajar IPA pada pokok bahasan Pembentukan Tanah dapat dijelaskan pada tabel berikut:

Tabel 3. Hasil Belajar IPA kelas V Siklus II

\begin{tabular}{|c|l|c|l|}
\hline $\begin{array}{c}\text { N } \\
\text { o }\end{array}$ & \multicolumn{1}{|c|}{$\begin{array}{c}\text { Nama } \\
\text { siswa }\end{array}$} & $\begin{array}{c}\text { Nilai } \\
\text { Siklus } \\
\text { I }\end{array}$ & Ketuntasan \\
\hline 1 & Fauzan & 70 & Tuntas \\
\hline 2 & $\begin{array}{l}\text { Dani } \\
\text { Firmansyah }\end{array}$ & 80 & Tuntas \\
\hline 3 & Riva Akbar & 75 & Tuntas \\
\hline
\end{tabular}

$$
\begin{aligned}
& \text { Ketuntasan kelas } \\
& \frac{\text { jumlah siswa yang tuntas }}{\text { jumlah total siswa }} \times 100 \\
& \text { Ketuntasan kelas }=\frac{4}{4} \times 100 \%=\mathbf{1 0 0} \%
\end{aligned}
$$

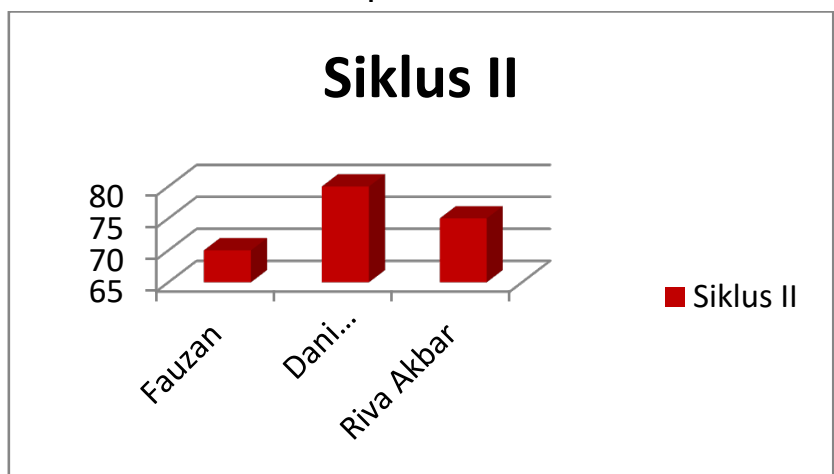

\section{Gambar 3. Grafik Hasil Belajar IPA kelas V Siklus II}

Dengan melihat tabel hasil belajar di atas, dapat diketahui bahwa hasil belajar pada siklus II mengalami peningkatan yang cukup pesat yaitu semua siswa di SLB - B \& Autis TPA Jember sudah berhasil sesuai dengan KKM bahkan di atas KKM yaitu sebesar $\quad 100 \%$. Hasil tersebut menunjukkan bahwa pada siklus II secara klasikal siswa telah tuntas, karena siswa yang memperoleh nilai di atas KKM lebih besar dari prosentase ketuntasan yang dikehendaki yaitu sebesar $85 \%$.

Hasil penelitian pembelajaran pada siklus I, untuk peningkatan hasil belajar IPA tentang Pembentukan Tanah di kelas V SLB - B \& Autis TPA Jember masih belum sepenuhnya dipahami siswa. Beberapa hal yang menyebabkan ini adalah sebagai berikut:

a. Siswa kurang termotivasi untuk belajar IPA

b. Metode yang diterapkan guru masih belum bisa membuat 
siswa aktif dalam pembelajaran di kelas.

c. Hasil akhir siklus pembelajaran ke I ini semakin meningkat dibanding sebelum siklus, dari ketuntasan rata-rata $33 \%$ menjadi 66\%. Namun, secara klasikal belum tuntas.

Pada siklus II ini pengamatan yang diperoleh adalah:

a. Antusias siswa untuk mengikuti pembelajaran semakin meningkat, karena pembelajaran dengan metode penemuan lebih jelas dan terarah.

b. Interaksi antar guru dan siswa juga sering terjadi karena guru memperhatikan dan menghargai ide atau pendapat siswa.

c. Hasil akhir siklus pembelajaran ke II ini semakin meningkat dibanding siklus I, dari ketuntasan rata-rata $66 \%$ menjadi 100\%. Dengan demikian, secara klasikal hasil belajar IPA dinilai tuntas.

Adapun perbandingan antara kedua siklus di atas, dapat dilihat pada tabel berikut ini:

Tabel 4. Perbandingan Hasil Belajar IPA Siklus I dan II

\begin{tabular}{|l|c|c|c|c|}
\hline Kategori & \multicolumn{2}{|c|}{$\begin{array}{c}\text { Siklus } \\
\text { I/Prosentase }\end{array}$} & \multicolumn{2}{c|}{$\begin{array}{c}\text { Siklus } \\
\text { II/Prosesentase }\end{array}$} \\
\hline Tuntas & 2 & $66 \%$ & 100 & $100 \%$ \\
\hline $\begin{array}{l}\text { Belum } \\
\text { Tuntas }\end{array}$ & 1 & $34 \%$ & 0 & $0 \%$ \\
\hline
\end{tabular}

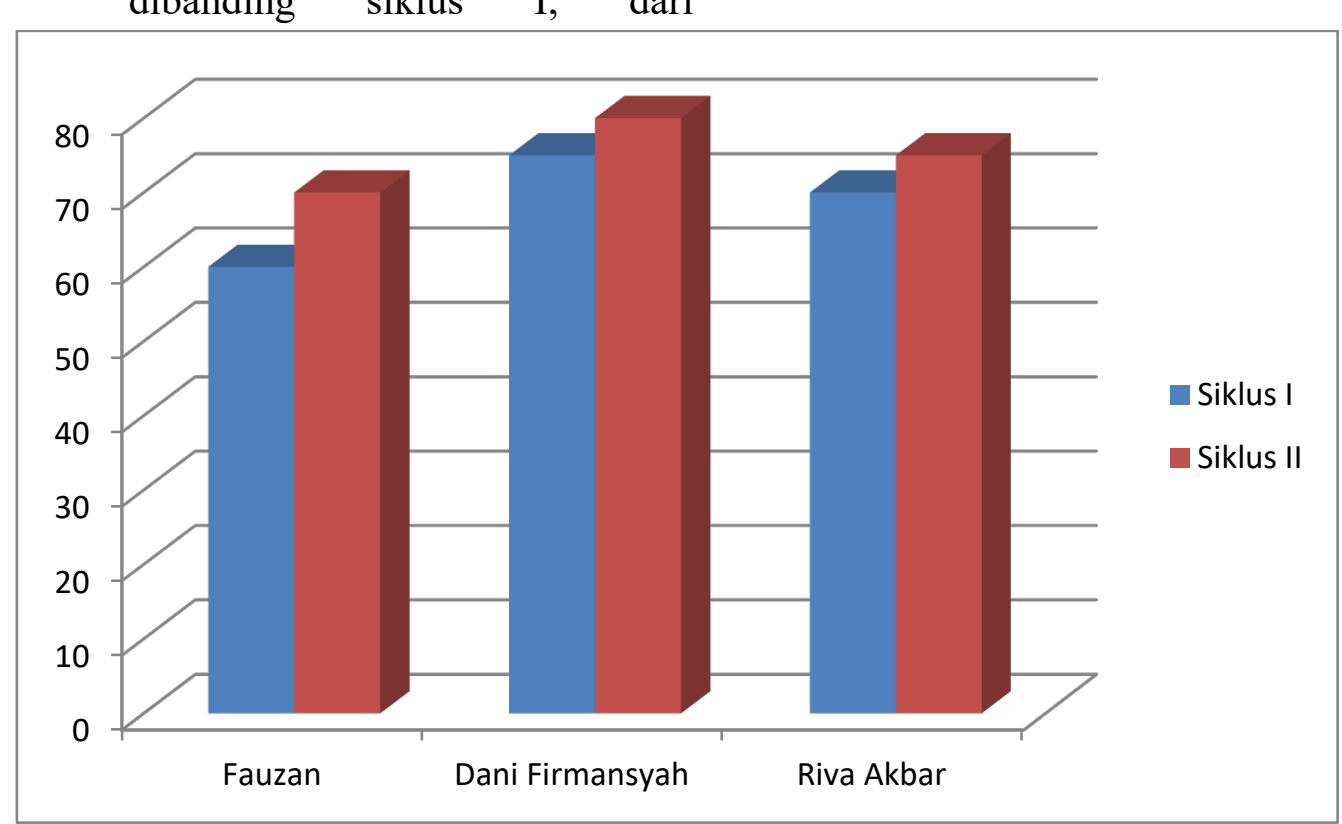

Gambar 4. Grafik Perbandingan Hasil Belajar IPA Kelas V Siklus I dan Siklus II

Berdasarkan tabel dan grafik di atas, maka dapat disimpulkan bahwa pada Siklus I, dari 3 siswa yang tuntas sebanyak 2 siswa (66\%) dan yang belum tuntas sebanyak 1 siswa http://doi.org/10.31537/speed.v3i2.281 lain (34\%). Sedangkan pada Siklus II, semua siswa telah tuntas (100\%). Jadi, dari Siklus I ke Siklus II ada peningkatan hasil belajar sebesar $34 \%$. 


\section{PENUTUP}

\section{Simpulan}

Penelitian Tindakan Kelas yang dilakukan peneliti dapat diambil kesimpulan bahwa: hasil belajar IPA pada pokok bahasan Pembentukan Tanah di kelas V SLB - B \& Autis TPA Jember dapat meningkat melalui penerapan Metode Discovery dengan Media Flashcard. Hal ini dapat dilihat bahwa pada Siklus I, dari 3 siswa yang tuntas sebanyak 2 siswa (66\%) dan yang belum tuntas sebanyak 1 siswa lain (34\%). Sedangkan pada Siklus II, semua siswa telah tuntas (100\%). Jadi, dari Siklus I ke Siklus II ada peningkatan hasil belajar sebesar 34\%.

\section{Saran}

Berdasarkan kesimpulan di atas dapat disarankan hal-hal sebagai berikut:

1. Kegiatan pembelajaran IPA yang selama ini menggunakan media dan metode kurang meningkatkan hasil belajar siswa, keaktifan siswa dan pemahaman terhadap materi sebaiknya menggunakan pembelajaran yang aktif, efektif, menyenangkan sesuai dengan situasi dan kondisi yang ada.

2. Dengan melihat hasil belajar siswa dalam menerapkan Metode Discovery dengan Media Flashcard yang mengalami peningkatan, tentunya bisa dikembangkan dengan metode, strategi, dan media pembelajaran yang lain yang dianggap lebih efektif.

3. Dengan adanya perbaikan pembelajaran diharapkan dapat meningkatkan profesional guru dalam mengemban amanat sebagai guru yang profesional.

\section{DAFTAR PUSTAKA}

Arikunto, Suharsimi, 2002, Prosedur Penelitian Suatu Pendekatan Praktek. Jakarta: Rineksa Cipta

Arsyad, A. 2006. Media Pembelajaran. Jakarta: PT Raja Grafindo Persada

Aswandi, 2019, Proses Sosial dan Interaksi Sosial Dalam Pendidikan, Jakarta: Rineka Cipta

Depdiknas, 2006, Standar Kompetensi dan Kompetensi Dasar Mata Pelajaran IPA, Jakarta: Depdiknas.

Hadis, Abdul, 2009, Pendidikan anak Berkebutuhan Khusus, Bandung: Alfiabeta

Indriana, Dina, 2011, Ragam Alat Bantu Media Pengajaran. Yogyakarta: Diva Perss

Nurkanca, 1990, Evaluasi Pendidikan, Surabaya: Usaha Nasional.

Poerwodarminto, 2007, Kamus Umum Bahasa Indonesia, Jakarta: Balai Pustaka

Rayandra, 2012, Kreatif Mengembangkan Media Pembelajaran. Jakarta: Gaung Persada Press

Rudi dan Riyana, 2007, Media Pembelajaran. Bandung: CV Wacana Prima 
Sudjana, Nana dan Ahmad Rivai, 2001, Media Pengajaran. Bandung: Sinar Baru

Sudjana, Nana, 1997, Penilaian hasil Proses Belajar Mengajar. Bandung: Sinar Baru

Sujarwanto, 2005, Terapi Okupasi Untuk Anak Berkebutuhan Khusus, Jakarta: Depdiknas

Suryosubroto, 1997, Proses Belajar Mengajar di Sekolah. Jakarta: PT. Rineksa Cipta

Sutrisno, Kresnahadi, dan Kartono, 2008, Pengembangan Pembelajaran IPA di SD, Jakarta: Dirjen Dikti Depdiknas

Undang-Undang Nomor 20 Tahun 2003 tentang Sistem Pendidikan Nasional

Wardani, 2004, Penelitian Tindakan Kelas, Jakarta: Universitas Terbuka

Zaini, Hisyam, 2008, Strategi Pembelajaran Aktif. Yogyakarta: Pustaka Insan Madani 